\title{
RESTRICTIONS ON FREEDOM OF MOVEMENT AND RESIDENCE IN THE EUROPEAN UNION DUE TO COVID-19
}

\begin{abstract}
Purpose: This article aims to determine if the restrictions on freedom of movement and residence in the European Union due to COVID-19 respect the core of this Human Right which is also one of the essential principles of the original European Communities.

Methods: With this purpose we have analysed the measures adopted in different countries along Europe in relation with the pandemic expansion's data. We analyse more deeply the regulations enacted in Spain and the European Union regulations in relation with the restrictions on mobility. The Spanish restrictions on freedom of movement have been selected for a particular treatment due to the fact that these limitations are considered the toughest in the entire Schengen area, and internally in Spain there is a broad discussion on the legitimacy of the limitations imposed on these fundamental rights through the regulation of the management of the COVID-19 pandemic.

Results: The results obtained lead us to know much better about the extent of the freedom of movement and residence in the European Union in crisis times, and the possibility of the reduction of its scope, depending on the circumstances.

Discussion: To achieve a better view of the main issue we discuss the legitimacy of the restrictions enacted as a response to the COVID-19 crisis to contain the pandemic expansion pondering the need and effectiveness of the restrictive measures.
\end{abstract}

KEYwORDS: freedom of movement, freedom of residence, pandemic, COVID-19, health crisis, European Union 


\section{INTRODUCTION}

The world is living currently the more dramatic pandemic that has occurred in a whole century. The COVID-19 outbreak has extended all over the word and the health crisis has been considered a pandemic since March 11, 2020, when the World Health Organization has stated so (Pérez P. and Real C.G., 2020).

The representation of the pandemic expansion and the data in each country are published by the World Health Organization, being representative the map that follows.

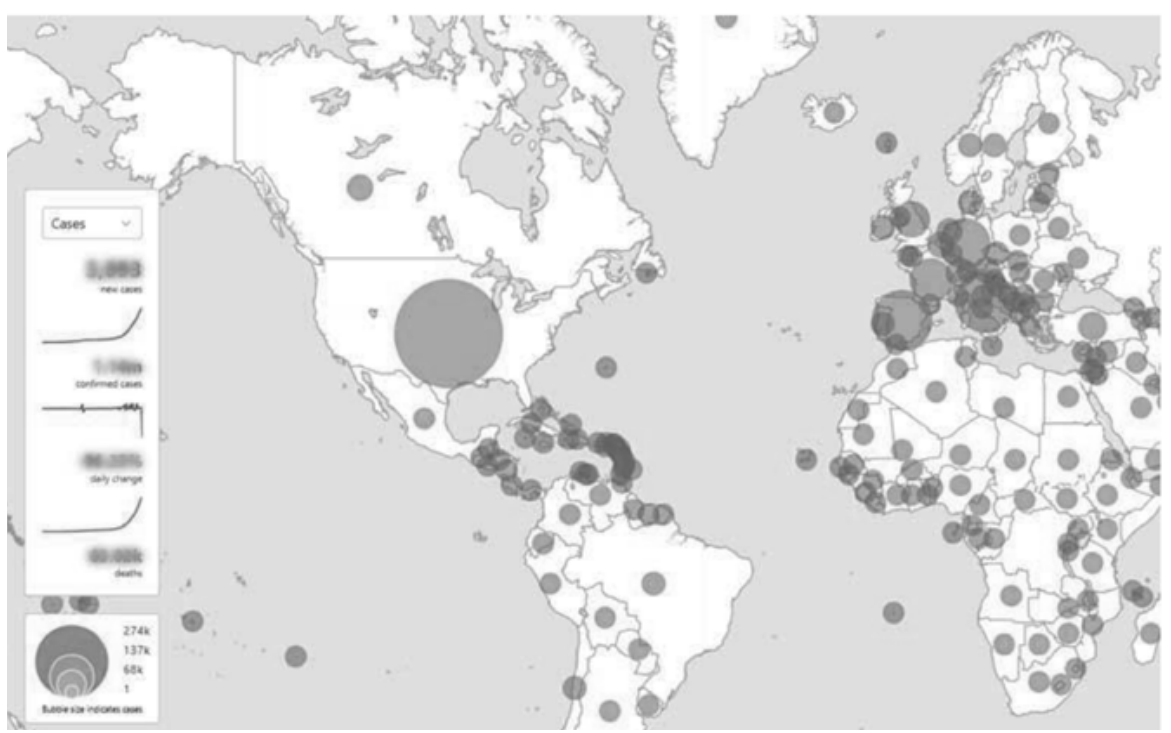

Figure 1. The map represents the countries, areas or territories with cases on June 9, 2020. Globally, as of 12:35pm CEST, 9 June 2020, there have been 7,039,918 confirmed cases of COVID-19, including 404,396 deaths, reported to WHO.

Source: https://www.who.int/emergencies/diseases/novel-coronavirus-2019

The evolution has been exponential since the beginning and has advanced a full speed, as we can see comparing the former image which represents the situation on June 9, with the situation tree months before, on March 14, showed in the figure 2 that follows. 


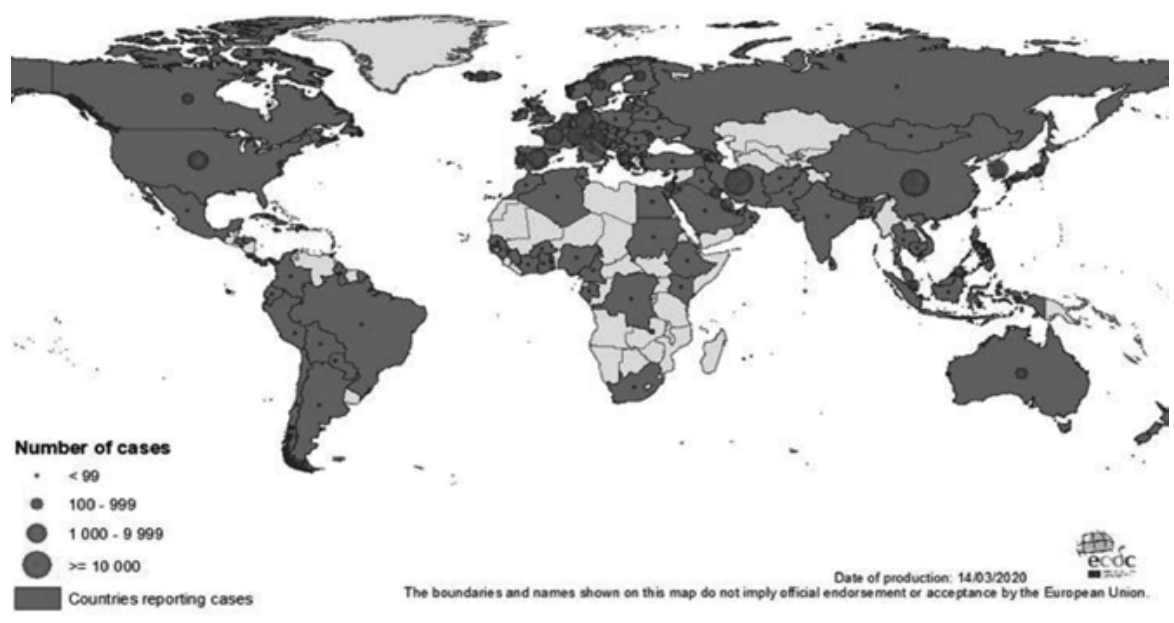

Figure 2. The map represents the countries, areas or territories with cases on March 14, 2020.

Source: Department of National Security, Spanish Government (https:/www.dsn.gob.es/es/ actualidad/sala-prensa/coronavirus-covid-19-14-marzo-2020)

With the finality of containing the effects of the COVID-19 caused by the coronavirus known as SARS-CoV-2, states all over the world have adopted a large range of measures which hold a common feature: restrictions on freedom as a Human Right. Mainly freedom of movement, freedom to circulate, freedom to travel, freedom to choose where to live, it is, freedom of residence. Freedom of movement and residence of people in the EU is also the cornerstone of Union citizenship, established by the Maastricht Treaty in 1992 and developed under Directive 2004/38/EC on the right of citizens of the EU and their families to move and reside freely within the EU. Its background is related to the Fundamental Right to liberty, which is declared on article 6 of the Charter of Fundamental Rights of the European Union, and on article 3 of the Universal Declaration of Human Rights of 1948. The Human Rights concept is an interchangeable one with those considered Fundamental Rights as the majority of the literature maintains (Aguilar Cavallo G., 2010, pp. 62-63), despite that there are other authors who consider that they are not the same (Martín-Retortillo Baquer L., 2006, p. 47). 
But in the European Union the meaning of the freedom of movement goes further because it implies the economic rise in the Schengen area. Notwithstanding, the importance of European social values have increased (Jiménez Garcia F., 2014, p. 108) as a consequence of the European Union evolution to a more integrated structure, so freedom of movement has currently a social meaning too.

Measures established to cope with the COVID-19 outbreak require a proper legal framework. Regulations in each European Union Member State have been profuse and rapidly enacted. As a consequence, the response of law to the situation has been adopted with improvisation that is what is not recommended to act like to face emerging crisis (Crespo I., Garrido A., y Medina R.M., 2017, p. 112). Notwithstanding, the relevance of the Fundamental Rights affected (Taléns Visconti E., 2020, p. 658) deserves a reflection about the compatibility of the limiting measures and the essence of those rights. Furthermore, it is a must to consider if in the European Union all of the limitations have supposed an essential change of the structural principles that guides its functioning. With this purpose in this paper we make a revision of the main measures adopted in Europe to cope with the pandemic and we ponder if the freedom of movement had been undermined through them.

\section{RESEARCH METHODS}

We analyze the measures enacted recently as a consequence of the COVID-19 health crisis. These measures and restrictions have the aim of protecting people's life and health so the crash with the freedoms we are reflecting on allows some restrictions but only when they are really needed. The determination of the criteria in which the legitimacy of restrictions lies is achieved through the ponderation of the restrictions in some European Union regulations. For doing that, it is necessary to start by fixing the real meaning of the freedom of movement and residence, and to follow with the restrictions imposed to it, valuing the need and proportionality of them in the COVID-19 crisis, because of the balance that we must encounter between all aspects of security and respect of Human or Fundamental Rights (Cerdá Guzmán, 2017, p. 1). 


\section{FREEDOM OF MOVEMENT AND RESIDENCE REAL MEANING IN THE SCHENGEN AREA}

The Human Right to liberty is declared as a Fundamental Right on article 6 of the Charter of Fundamental Rights of the European Union (2000/C 364/01) that embodies on article 45 the freedom of movement and residence as a citizens' right. In the European Union its meaning goes further because it is involved with the basis of the development of the Common Market and lately with the economic rise in the Schengen area. The Schengen zone was created on June 14, 1985, and in that moment, it was extended through five countries that signed the Schengen Treaty (Vervaele J., 2001, p. 45), but it has been in a constant progress of expansion becoming much than an economic principle, cause it has nowadays a social connotation too (Van Outrive L., 2001, pp. 45-50).

For that reason, the freedom of movement and residence of people in the EU equally than the free movement of capitals, is more than an essential principle of the European Union (Sanchez-Bella Carswell, 1980, p. 632), is the cornerstone of Union citizenship, established by the Maastricht Treaty in 1992 and developed under Directive 2004/38/EC on the right of citizens of the EU and their families to move and reside freely within the EU. But in its origin in the European Union, this principle is related to the free circulation of workers, professionals, and capitals. Thus, the heading of Title III of the Treaty of European Economic Community referred the "free movement of persons" (articles 48, 49, 50 and 51) are unequivocally regulating the free movement of workers within the original European Communities (Linde Paniagua, 2003, p.15). But nowadays its scope is huger due to the evolution of the original European Communities into the European Union, in where the constitutional values are reinforced, as a consequence of an almost Constitutional European process (Tomás Mallén B., 2004, p. 31), that some say that is an inevitable process but impossible at the same time (Menéndez A.J., 2012, p. 97), due to the lack of European democratic and constitutional legitimacy (Aguilar Calahorro A., 2014, p. 338).

The Treaty of Functioning of the European Union on its article 57 relates to the freedom for goods, capital and persons, and on articles 202 and 203 it is declared that these freedoms are subject to the provisions 
relating to public health, public security or public policy, which shall be regulated by provisions adopted by the Council in accordance with a special legislative procedure, and it shall act unanimously on a proposal from the Commission, and after consulting the European Parliament. In these sense, free movement had been developed through Regulation (EU) No 492/2011 of the European Parliament and of the Council of 5 April 2011, on freedom of movement for workers within the Union, and in Directive 2014/54/ EU of the European Parliament and of the Council of 16 April 2014, on measures facilitating the exercise of rights conferred to workers. It has also been developed further by the case-law of the European Court of Justice (European Commission -report-, 2018, p. 1). Despite the fact that this regulation is referred to the Common Market, there could be limitations on that freedom due to causes of health and security that can be useful to consider as a general rule.

\section{MeAsures TAKEN TO FACE COVID-19 CRISIS IN EUROPEAN COUNTRIES}

As a consequence of the pandemic due to COVID-19 "State authorities are having to deploy maximum resources to combat the spread of the disease and protect lives. Decisions are being made rapidly and, even though wellintended, some can inadvertently have adverse consequences" (United Nations -report-, 2020, p.3). These measures must be proportionate to the pandemic using Human rights as a guide, as United Nations has state in its report of April 2020 so-called COVID-19 and Human Rights We are all in this together.

In all the countries affected severely by the COVID-19 pandemic the lockdown has been a common measure, but with different intensity, and it implies the close of borders too.

So, Italy was the first country with areas forced into confinement that were in the Lombardy region. Specifically, ten towns in the province of Lodi were isolated in late February. On March 9, after an accelerated increase in the number of confirmed cases, the Government of Italy declared quarantine for the entire country. On March 21, Italian Prime Minister announced more drastic measures, which included closure of 
all productive activities. The Italian Prime Minister again extended the restrictions and confinement until May 3, with the aim of containing the spread of the coronavirus. The first phase for de-escalation in this country began on Monday, May 4, which is being progressive, and in June there are still some restrictive measures.

In Germany, the contagion rate has also been high, but the death rate is well below levels. Regarding containment measures, the German government originally ordered the closure of all shops, schools, universities, leisure centres and any non-essential premises to deal with this pandemic. As in other countries, basic necessities, such as supermarkets or pharmacies, remained open. Commuting to work or daily physical activity was also allowed. However, the country has not imposed population confinement, but restrictions. These measures were extended until May 3. On May 4, the gradual reopening of the country began and schools were reopened for higher grades, except in the hardest hit by the epidemic.

France is one of the countries with the highest number of infected people, and it was on March 17, to face its expansion, when the French Government decreed the confinement of the population, which was extended until May 11. From this date the country will begin the reopening of some establishments gradually, such as nurseries, educational centres, schools and institutes. Regarding mobility, French citizens are allowed to move to a maximum distance of 100 kilometres from their usual home.

In the United Kingdom, although at first the British Government was not going to order any confinement or isolation of the population, it had to change its strategy due to the increase in cases. Thus, on March 23, a mandatory confinement was ordered, situation that lasted until May 7, beginning the progressive de-escalation from that moment on.

Portugal decreed quarantine on March 18 with one deceased person and 448 infected people, concluding the state of emergency on May 2, although since then the situation has been a "state of calamity", a situation that existed at start of the pandemic. Austria did so on March 16 with 959 cases and a fatality as well, being the first country to initiate progressive de-escalation since April 14. Belgium, meanwhile, did so on March 18 with 14 people dead and 1,486 cases. 
In Spain, the state of alarm was set through Royal Decree 463/2020 of March 14, with effect from March 15, being the data offered by the Ministry of Health, at that time, the following: 5,753 of reported cases nationwide, which represented 12.23 cases per 100,000 inhabitants, including 136 deaths and 293 admitted to the ICU. Madrid was the community with the most affected people (2,940 people) followed by Catalonia (509 people), the Basque Country (417 people), Castilla-La Mancha (289 people), La Rioja (278 people) and Andalusia (269 people). The whole situation is represented in figure 2.

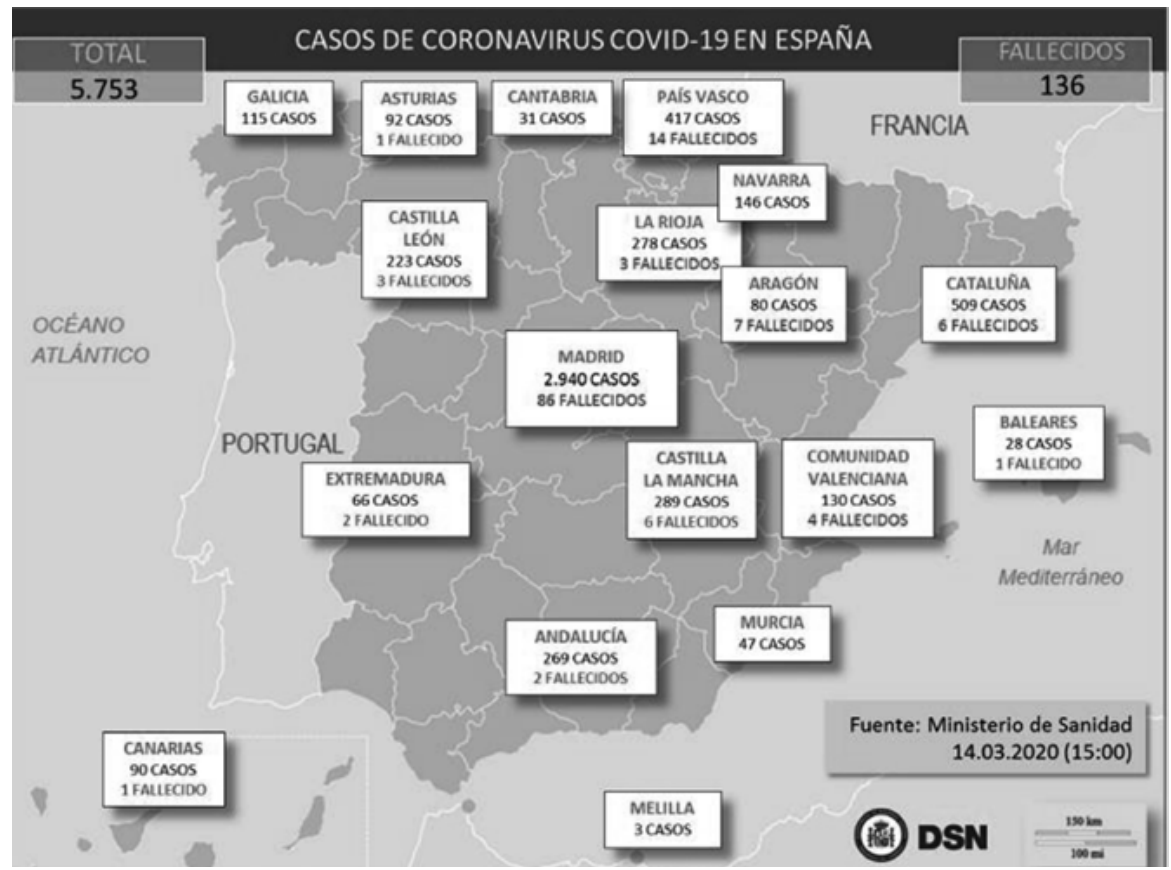

Figure 3. Risk Evaluation

Source: Department of National Security, Spanish Government(https://www.dsn.gob.es/es/ actualidad/sala-prensa/coronavirus-covid-19-14-marzo-2020)

As a consequence, it was the middle of March when the majority of European countries adopted measures of lockdown despite that the data of the infected people there were not the same in each one. 

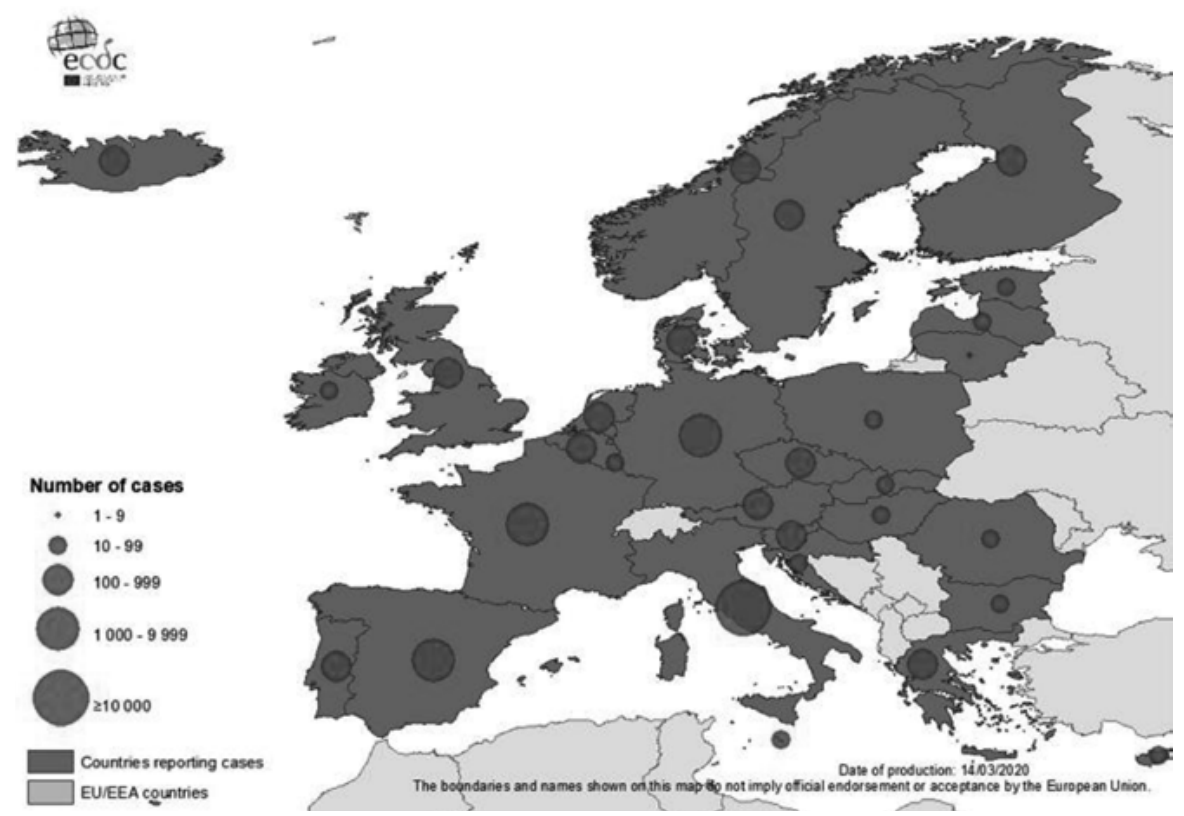

Figure 4. Reported cases on March 14, 2020. In that moment, with those data, the European Center for Disease Prevention and Control (ECDC) was maintaining its assessment of infection risk moderate to high

Source: Department of National Security, Spanish Government (https://www.dsn.gob.es/es/ actualidad/sala-prensa/coronavirus-covid-19-14-marzo-2020)

The analysis of the moment in which the lockdown measures were adopted in relation to the number of cases of people infected and deceased has shown that in those countries where the measures were adopted with lower rates of infected people, the impact of the pandemic was lower. The direct relation between these data shows that confinement and restrictions on freedom of movement have been necessary to manage the health crisis to protect citizen's lives, health, and well-being. 


\section{SPANISH RESTRICTIONS AND THE EUROPEAN UNION CRITERIA ABOUT LIMITING FREEDOM OF MOVEMENT}

The Spanish restrictions on freedom of movement are considered the toughest in the entire Schengen area, and internally in Spain there is a broad discussion on the legitimacy of the limitations imposed through the regulation of the management of the COVID-19 pandemic. In Spain, the measures taken through the so-called state of alarm has arose a discussion about the sufficiency and adequacy of the current regulation to sustain the whole framework to face a pandemic, and about whether the measures adopted in the Royal Decree 463/2020, of March 14, that sets in Spain the state of alarm, respect the Fundamental Rights and Administrative Spanish organization. Despite of being a Decree, from a normative point of view it is considered that its value is equally as the laws that it can affect (Martín Lorenzo B., 2020, p.23). The state of alarm has been extended six times with the authorization of the Congress of Deputies, extensions that are reflected in: Royal Decree 476/2020, of March 27; Royal Decree 487/2020, of April 10; Royal Decree 492/2020, of April 24; Royal Decree 514/2020, of May 8; Royal Decree 537/2020, of May 22; and Royal Decree 555/2020, of June 5.

After two and a half months of confinement, with some liberalization of the strictest initial measures of social distancing in recent weeks, June 1, 2020 was the first day without any deceased officially recorded in Spain by COVID-19 (RPP noticias, June 2, 2020), a figure that the following days still fluctuated, but overcoming the worst times, when on April 2, 2020 the highest peak had been reached with 950 deaths in a single day (El Mundo, April 8, 2020), according to official sources as well. Therefore, it is evident that the lockdown was necessary to stop the spread of the pandemic.

Regarding this issue, those authors who maintain that the state of alarm is not proper are defending that the situation requires a more exceptional measure which is the state of exception. The difference between both of them is material and formal too. Material because the state of exception could include the suspension of some Fundamental Rights, while the state of alarm only can suppose the limitation of them, so that is a lesser degree of affectation of these rights. Other difference is formal, because of the requirement of previous authorisation of the Congress to set a state of 
exception, authorisation that is not required in order to set a state of alarm, which only needs the authorisation of the Congress to be extended after the first fifteen days from the declaration of the state of alarm.

These legal measures affected freedom of movement, and indirectly, the free choice of residence during the period in which the restrictions have lasted, included on article 19 of the Spanish Constitution, and related with articles 6 and 45 of the Charter of Fundamental Rights of the European Union, aswell with article 3 of The Universal Declaration of Human Rights.

The application of the state of alarm is what is normatively provided on articles 4 b) and 11 of the Spanish Organic Law 4/1981 to manage any epidemic in Spain (Gómez Zamora L.J., 2020, p. 25). But, many authors consider the measures taken to deal with COVID-19 crisis exceed what is allowed in the state of alarm, and it would be more proper to declare a state of exception (Álvarez García, 2020, p.20), requiring the former approval of the Congress of Deputies, in accordance with article 13 of the Spanish Organic Law 4/1981. Those who support this thesis are considering that the current situation has meant the suspension of freedom of movement recognized on the article 19 of the Spanish Constitution, and not only its limitation, relying article 55 of the Spanish Constitution.

In our opinion, the solution of this discussion depends on the extent of the measures adopted, have they meant the limitation or the suspension of free movement? The distinction between limitation of mobility and suspension of freedom of movement, a priori, is really difficult to do. To face a health crisis, what the regulation provides is the declaration of the state of alarm, but it could be impossible to distinguish where the limitations of the fundamental rights and freedoms end, and where a non-lawful suspension reserved exclusively for states of exception and siege begins (Requejo Rodríguez, 2001, p. 115). The lack of clarity between what is a limitation and what is a suspension of such rights and freedoms, necessarily leads us to emphasize the restrictive interpretation of the limitation of rights and freedoms in the event of a state of alarm (Requejo Rodríguez, 2001, p. 136), a restrictive interpretation that should be applied in any case of restriction of rights, but in this case, with even more reason. The lack of delimitation of 
the restrictions in the two scenarios should not imply the removal of other guarantees that the legal system requires (Fernández Segado, 1983: p. 37), both material and formal.

In the case of the state of alarm declared in Spain, the guarantees to declare the state of alarm have been accomplished, but if we consider that the fuzzy line that differentiates limitation and suspension of rights and freedoms has been crossed, we must reflect about if the requirements for a state of exception have been observed too. Regarding that, the authorizations of Spanish Congress for the six extensions of the state of alarm could serve as a formal guarantee for these purpose, since each extension of the state of alarm can be agreed by the Government through decree of the Council of Ministers, with the prior authorization of the Congress, pursuant to article 116.2 CE, which are the same formal requirements to declare the state of exception, as provided on article 116.3 CE. So, does each extension of the state of alarm validate the possible formal defects of the state of exception, in order to legally support the suspension of rights? Whatever the answer to this question is, what is clear is that the material difference between limitation and suspension of rights is difficult to do in some scenarios, and the formal requirements could be validated.

In the evolution of the current health crisis we observe that the lockdown of citizens was a must to stop the spread of the pandemic, as it has been showed through the data of some European countries. The protection of life, health and physical integrity of European citizens has required the confinement, so we can state that this measure was proportionate using Human rights as a guide. In these sense, they must prevail over other rights and freedoms using them as a guide, as declared the United Nations report of April 2020: COVID-19 and Human Rights, We are all in this together, that states: "Human Rights law recognizes that national emergencies may require limits to be placed on the exercise of certain human rights. The scale and severity of COVID-19 reaches a level where restrictions are justified on public health grounds" (United Nations -report-, 2020, p.3).

The European Union scope Regulation (EU) 2016/399 of the European Parliament and of the Council of 9 March 2016 establishing a Code of Union rules for the crossing of people across borders (hereinafter Schengen Borders 
Code), contemplates the power of the Member States of the European Union to impose, when exceptional circumstances exist and for a limited time, the temporary reestablishment of border controls at the internal borders of the Schengen area, under article 28. In fact, the Schengen Borders Code provides in its number 6 that it contributes "to the fight against clandestine immigration and human trafficking, as well as the prevention of any threat to internal security, public order, public health and international relations of the Member States", so it is totally allowed to incorporate control borders to face health crisis.

In the case of the pandemic due to COVID-19, the need to protect the public health justifies the borders controls, because it is a «Threat to public health» defined in the Schengen Borders Code on article 2, number 21 as «any disease of epidemic potential defined by the Health Regulations International World Health Organization and other infectious diseases or parasitic diseases contagious when they are subject to protection provisions applicable to nationals of a Member State».

Following this line, the European Union Agency for Fundamental Rights has assess the affection of the human rights in the management of the COVID-19 crisis, valuing among all the right to life, health and physical integrity for people living in the European Union, and it does not involve an involution of the European Union development (Barone, 2017, p. 291). Over this premise the European Union Agency for Fundamental Rights has published two bulletins so-called Coronavirus Pandemic in the EU - Fundamental Rights Implications, corresponding to February 1 to March 20 of 2020, and to March 20 to April 30 of 2020. In this scope, the restrictions to the freedom of movement are justified in case of "diseases with epidemic potential", such as COVID-19, if the principle of proportionality is complied, and when there are not discrimination between Member States' own nationals and resident European Union citizens.

\section{Conclusion}

COVID-19 health crisis has supposed the limitation of freedom of movement and de free election of residence during the lockdown and similar measures adopted in almost all the countries of the European Union. These 
limitations have implied the reduction of the freedom of movement and residence and the reduction of an essential principle in the Schengen area which is a cornerstone of the European Union. In some countries, it has arisen a discussion regarding if the restrictions implemented were adopted in a legal way or if it has undermined Fundamental Rights.

The whole issue needs to be analyzed from the opposite point of view. Whereas the lockdown has affected those freedoms, the confinement was established to protect others Fundamental and Human Right as life, health, and physical integrity of citizens. The discussion about the reduction of freedom of movement as a liberty must be overcome putting the focus on it utility to protect life and health of people, if the measures of confinement are taken with proportionality and observing the principle of equal treatment between Member States' own nationals and other resident European Union citizens.

These parameters leads us to conclude that the confinement measures were correctly adopted under the premise that the health and the life must be over all Fundamental Rights, since they are the material support of other Fundamental Rights and Freedoms. Despite this, in our opinion, some European guidelines could be adopted to harmonize the restrictions in the whole Schengen area with the purpose of stablishing some uniform criteria in all the Member States that could be useful as criteria to ponder the necessity of applying the restrictions on mobility in future cases.

\section{Bibliography}

Aguilar Calahorro A. (2014), "La decisión Pringle en el proceso de constitucionalización de la Unión Europea”, Revista Española de Derecho Constitucional, núm. 101, mayo-agosto, pp. 337-380. ISSN 0211-5743.

Aguilar Cavallo G. (2010), "Derechos Fundamentales-Derechos Humanos. ¿Una distinción válida en el siglo XXI?”, Boletín Mexicano de Derecho Comparado, número 127, pp. 15-71. ISSN 2448-4873.

Álvarez García (2020), "Estado de alarma o de excepción", Estudios Penales y Criminológicos, vol. XL, 2020, pp. 1-20. ISSN 2340-0080.

Barone A. (2017), "Schengen et l'art de gouverner la mobilité", Eikasia Revista de Filosofía, pp. 281-291. ISSN 1885-5679. 
Cerdá Guzmán C., (2017), “Los derechos fundamentales y la lucha contra el terrorismo: Francia bajo estado de emergencia”, en Revista de Derecho Comunitario Europeo núm. 27. Enero-Junio de 2017, Centro de Estudios Políticos y Constitucionales, pp. 1-17. ISSN 1138-4026.

Crespo I., Garrido A., y Medina R.M. (2017), "La comunicación de crisis en la administración pública española: análisis de evidencia empírica”, GAPP. Nueva Época - No 18, noviembre 2017, pp. 110-134. ISSN 1989-8975.

Fernández Segado F. (1983) "Naturaleza y régimen legal de la suspensión general de los derechos fundamentales", Revista de derecho político, № 18-19, pp. 31-58. ISSN 2174-5625.

Gómez Zamora L.J. (2020), "Breve estudio de las medidas adoptadas durante el estado de alarma para la gestión de la situación de crisis sanitaria ocasionada por el COVID-19", Análisis jurídico derivado del estado de alarma por la crisis sanitaria ocasionada por el COVID-1, Gabilex No 21 No Extraordinario 2020, Castilla-La Mancha, pp. 19-72. ISSN 2386-8104.

Jiménez Garcia F. (2014), “Tomarse en serio el derecho internacional de los derechos humanos. Especial referencia a los derechos sociales, el derecho a la vivienda y la prohibición de los desalojos forzosos", Revista Española de Derecho Constitucional, Centro de Estudios Políticos y Constitucionales, núm. 101, mayoagosto, pp. 79124. ISSN 0211-5743.

Linde Paniagua, E. (2003), "La libre circulación de los trabajadores versus libre circulación de las personas. La ciudadanía europea”, Revista de derecho de la Unión Europea, $\mathrm{N}^{\circ} .5$ (Ejemplar dedicado a: La Europa social. La Europa de la solidaridad), pp. 15-36. ISSN 1695-1085.

Martín Lorenzo B., (2020), "Medidas de protección a las personas mayores durante la crisis sanitaria ocasionada por el COVID-19”, Análisis jurídico derivado del estado de alarma por la crisis sanitaria ocasionada por el COVID-1, Gabilex No 21 No Extraordinario 2020, Castilla-La Mancha, pp. 19-50. ISSN 2386-8104.

Martín-Retortillo Baquer L., (2006), Vías concurrentes para la protección de los derechos humanos, Thomson Reuters-Civitas, Navarra.

Menéndez A.J. (2012), "La mutación constitucional de la Unión Europea”, Revista Española de Derecho Constitucional, núm. 96, septiembre-diciembre, pp. 41-98. ISSN 0211-5743.

Pérez P. and Real C.G. (2020), "La OMS declara oficialmente el coronavirus como una pandemia”, El Mundo (diario digital), March 11, 2020. Available in: https:// www.elmundo.es/ciencia-y-salud/salud/2020/03/11/5e694c48fc6c8350428b4680. html. 
Requejo Rodríguez P, (2001) “Suspensión o supresión de los derechos fundamentales?”, Revista de derecho político, No 51, pp. 105-138. ISSN 0210-7562.

Sanchez-Bella Carswell, (1980) "Libre circulación de capitales en la comunidad económica europea”, Documentación Administrativa, INAP, Madrid, 1980, p. 631-650.

Taléns Visconti E., (2020) "La Prevención de Riesgos Laborales ante la crisis sanitaria del COVID-19: principales medidas y responsabilidades", Actualidad Jurídica Iberoamericana No 12 bis, mayo 2020, pp. 656-667. ISSN 2386-4567.

Tomás Mallén B. (2004), El derecho fundamental a una buena administración, editado por Instituto Nacional de Administración Pública, Madrid. ISBN 8473512200.

Van Outrive L. (2001) "Historia del Acuerdo y del Convenio de Schengen", Revista Cidob D’afers Internacionals 53. Ciudadanía Europea e inmigración, Barcelona, Ed. Fundación CIDOB, pp. 43-61.

Vervaele J. (2001), “Judicial Co-operation in the European Union”, Integrated security in Europe, a democratic perspective, News of the College of Europe - Nouvelles du Collège d'Europe Collegium n ${ }^{\circ} 22$, Bruges, p. 44-50.

\section{Other sources}

Diario digital El Mundo, April 8, 2020, last entrance June 2, 2020 in: https://rpp. $\mathrm{pe} / \mathrm{mundo} /$ actualidad/espana-se-registra-el-primer-dia-sin-fallecidos-porcoronavirus-noticia-1269879.

Report from the Commission to the European Parliament, the Council and the European Economic and Social Committee on the implementation of Directive 2014/54/EU of the European Parliament and of the Council of 16 April 2014 on measures facilitating the exercise of rights conferred on workers in the context of freedom of movement for workers, Brussels, 4.12.2018, $\operatorname{COM(2018)~} 789$ final.

RPP noticias, "España: registra el primer día sin fallecidos por coronavirus", June 1, 2020, last entrance June 2, 2020 in: https://www.elmundo.es/ciencia-y-salud/salud/2020/04/08/5e8d9ce1fc6c8309438b45b9.html.

United Nations report on COVID-19 and Human Rights We are all in this together, April 2020. 